\title{
Propolis as an adjunct to prevention and treatment of radiotherapy- and chemotherapy-induced oral mucositis
}

\author{
Izabel Cristina Gomes de Mendonça* \\ Health Research Master, Cesmac University Center, Maceió, Alagoas, Brazil
}

\begin{abstract}
Oral cancer is one of the eleven most prevalent cancers in the world. Treatment is surgery associated to radiotherapy and/or chemotherapy, although, therapy side effects deeply affect patients' life quality. Oral mucositis is the most frequent and uncomfortable side effect, and severe cases can cause treatment interruption and hamper disease control. There is no effective treatment against oral mucositis, thus, natural medicine is a promising source of effective substances when conventional treatment failed or selected resistant bacterial strains. Propolis is a natural substance available on pharmaceutical market. This research aimed to evaluate scientific publications concerning propolis anti-inflammatory activity, as well as its anti-bacterial action against oral flora micro-organisms, and to evaluate propolis employability as an adjunct to prevention and treatment of radiotherapy- and chemotherapy-induced oral mucositis. Propolis potential against oral mucositis is due to the association between its antifungal, antibacterial and antiviral properties, besides, its healing, antiulcer and anti-inflammatory activities.
\end{abstract}

\section{Introduction}

Oral cancer is one of the eleven most prevalent cancers among world population, approximately 150,000 people die of oral cancer per year and its incidence increased in the last years [1,2]. Treatment of choice is surgery associated to radiotherapy and/or chemotherapy [3], which is efficient in early stages of the disease, although, side effects deeply affect patients' quality of life.

Mucositis is considered the most severe non-hematological complication of cancer treatment. Extreme cases can interrupt treatment and hamper disease control $[5,6]$. Mucositis symptoms include severe pain, spontaneous bleeding, and mastication, swallowing and speaking difficulties; it is considered the most debilitating acute reaction of oral cancer treatment [4,7]. Mucositis etiology is associated to epithelial cells death, resulting in an atrophic epithelium and exposing connective tissue to opportunist microorganism's invasion normally present in the mouth, especially Candida albicans [4].

There is no effective treatment to oral mucositis [8]. Therapies aim to moderate painful symptoms through analgesics, accurate oral hygiene in order to induce selective decontamination and decrease opportunist infections, immunomodulatory drugs, growth factors, laser therapies, cryotherapy etc. Symptoms completely disappear with radiotherapy and chemotherapy conclusion [6].

Natural medicine is a promising source of effective substances with antibacterial action when conventional treatment failed or selected resistant bacterial strains $[9,10]$. Most natural antibiotics have complex chemical structures important on specific interactions, and are more easily recognized by pathogenic bacteria macromolecules targets. In addition, organisms from new ecosystems are frequently associated to a new chemical diversity, thus, pharmaceutical industry resumed researches on new antibiotics of natural origins [11].

Propolis is a natural substance alternative available on pharmaceutical market. It is a complex, non-toxic resin, collected by bees from tree buds, flowers and plants exudate, it has antibacterial, antifungal, antiviral, anti-inflammatory, liver-protecting properties, besides, antitumour, immunomodulatory and healing activities, among others $[12,13]$. This biological potential results from synergism between propolis compounds, enhancing their effects. Studies confirm propolis synergic activity associated to antibiotics against bacterial strains resistant to benzylpenicillin, tetracycline and erythromycin. In conclusion, propolis synergic action is relevant and represents an effective alternative to synthetic antibiotics $[12,14,15]$.

This research aimed to evaluate scientific publications concerning propolis anti-inflammatory activity, as well as its antibacterial action against oral flora micro-organisms, and to evaluate propolis employability as an adjunct to prevention and treatment of radiotherapy- and chemotherapy-induced oral mucositis.

\section{Propolis chemical composition and biological activity}

Pharmaceutical laboratories commonly use natural products as a rich, promising and alternative medication source. Propolis has attracted scientific attention, due to its multiple pharmacological properties related to its chemical composition. Various studies invitro and in-vivo aimed to characterize and comprehend propolis bioactivities and its isolated compounds, as well as to evaluate and validate its therapeutic potential [16]

Propolis is found worldwide, and its singular chemical composition is related to climate, local flora diversity and bee specie in order to define its physical, chemical and biological properties [15,17]. Three

Correspondence to: Izabel Cristina Gomes de Mendonça, Health Research Master, Cesmac University Center, 161 Joaquim Nabuco Street, Farol. Maceió, Alagoas, 57051-410, Brazil, Tel: +55 823032 3115; +55 8299968 0062; E-mail: belgomess@gmail.com

Key words: propolis, oral mucositis, treatment

Received: July 20, 2016; Accepted: August 04, 2016; Published: August 08, 2016 
hundred compounds are responsible for these properties, which indicate propolis great chemical diversity and difficult standardization [18].

Phenolic compounds are currently found among isolated compounds of propolis samples collected from different locations on earth [19-23], especially flavonoids, isoflavonoids, phenolic acids, caffeic, and aromatic compounds [13,24], responsible for antibacterial, anti-inflammatory, antioxidant, antiviral, antifungal, and anticarcinogenic actions [25-27].

Caffeic acid phenethyl ester (CAPE) is a propolis' important active compound, which possesses anti-inflammatory and immunomodulatory properties. It is a potent and specific inhibitor of nuclear transcription factor NF-kappa B (NF- $\kappa B)$ activation, that regulates expression of gens related to immunological and inflammatory responses, which can provide molecular basis of propolis' anti-inflammatory and immunomodulatory activities [28,29]. Bufalo et al. [30] suggest that propolis anti-inflammatory effects are related to inhibition of nitric oxide production (inflammatory mediator) within macrophages. According to Paulino et al. [31], propolis antiinflammatory action is also related to selective inhibition of COX-2, promoted by phenolic compounds present in its composition.

Propolis antibacterial activity against Gram-positive and Gramnegative bacteria, yeasts, and bacteria resistant to antibiotics has been widely studied. Although, mechanism of action has not been entirely understood, researchers consider that specific compounds, such as rutin, quercetin and naringenin, are substantial for its antibacterial activity, increasing bacterial membrane permeability, and decreasing adenosine triphosphate (ATP) production and mechanisms of transport through membrane. Synergism between propolis and synthetic antibiotics increases its antibacterial effect. This activity is strictly related to polyphenols and flavonoids concentration present in studied samples [13].

Wound healing is another important therapeutic indication of propolis [32-35]. Barbosa et al. [36] revised scientific studies and emphasized propolis efficiency on wounds treatment, acting as a healing agent and natural antibiotic. In addition, they associated propolis properties to the method, extraction location and product concentration.

Studies demonstrated propolis capacity to promote keratinocytes proliferation, stimulation of glycosaminoglycan deposition on the wounds, and modification of chondroitin sulfate/dermatan structure. Propolis efficacy on second-degree burns healing process indicates that propolis promotes wounds debridement, collagen synthesis stimulation, and inflammation reduction. Propolis mechanism of action on wound healing process is controversial, although, evidences affirm the mechanism is mainly based on synergism between its compounds, and its antimicrobial and anti-inflammatory properties [13].

\section{Propolis action on mucositis}

Mucositis, inflammation and ulceration on oral mucosa, is an uncomfortable sequel of cancer treatment. Onset occurs during radiotherapy and/or chemotherapy, due to cellular division interference and non-differentiation of cancer cells, which rapidly divide themselves, from normal cells with the same growth pattern, such as oral mucosa. Failure on cells reposition promotes epithelial rupture, exposing connective tissue and favoring opportunist microorganisms invasion, which substantially exacerbates clinical status of mucositis $[37,38]$.
According to Simões, Castro and Cazal [38], there is a correlation between oral mucositis lesions and colonization by candida. Authors affirm treatment decreases patients' defenses, interrupting oral microbiota balance, and increasing Candida albicans population. This fungus is present over $30 \%$ to $50 \%$ of population without prejudice to the host, although, candida can become pathogenic during immunity deficit conditions, exacerbating oral mucositis symptoms and becoming more resistant to conventional treatments.

Mucositis care is limited to preventive measures, pain control and patients nutrition, cure is obtained only on cancer treatment conclusion. Prevention and control methods of mucositis include laser therapy and drugs to quell opportunist infections [39,40]. Drugs normally used to treat candida infections are polyenes and azole derivatives. However, these medications have undesirable adverse reactions and toxicity, besides, resistant strains have been described in literature [41]. Propolis is a promising option available among natural products, it is a non-toxic substance in recommended therapeutic doses, and possesses synergic effect between its compounds and when associated to antibiotics [15].

Javadzadeh et al. [42] conducted a triple blind, randomized clinical trial in order to test a propolis $3 \%$ aqueous antiseptic in head and neck cancer patients suffering from radiotherapy-induced mucositis. Their findings indicate it is a safe and efficient product of prevention and treatment of radiotherapy- induced mucositis. Another study evaluated a mucoadhesive gel containing propolis $5 \%$ in 24 adults with cancer during radiotherapy. Patients used the gel one day before radiotherapy beginning and during two weeks after treatment conclusion. By the end of research, 20 patients did not developed mucositis, two developed oral mucositis Grade 1 (according to mucositis grading scale) and two developed mucositis Grade 2; candida infection was not detected among patients [43]. This result indicates propolis can reduce oral mucositis symptoms and prevent lesions occurrence.

Propolis reduced and detained radiation induced mucositis in rats [44]. Benderli and Deniz [45], noticed propolis was efficient to reduce mucositis severity in rats, and, in addition, rats treated with propolis had their biochemical and histopathological parameters normalized compared to group with isolated irradiation.

As mentioned before, radiotherapy- chemotherapy- induced epithelial alterations on oral mucosa are exacerbated due to oral microorganisms' invasion, mainly candida, thus, controlling this fungus is essential to relieve mucositis. Propolis antifungal activity over Candida albicans was verified by many researchers [46-51]. Freires et al. [51] considered propolis a promising substance for oral candidiasis treatment after observing the strong anti-candida activity of propolis samples used in their research.

Siqueira et al. [52] evaluated fungistatic and fungicidal activities of a Brazilian red propolis ethanolic extract, against different candida species compared to chlorhexidine, and using fluconazole as control. All candida species were susceptible to propolis and chlorhexidine, although, five samples of C. albicans, C. tropicalis and C. glabrata were resistant to fluconazole antifungal activity. Szweda et al. [47] also noticed in their research that propolis was active against fungus strains resistant to fluconazole, confirming Siqueira et al. results.

A similar investigation evaluated susceptibility of Candida albicans strains collected from HIV-positive patients to an ethanolic extract of propolis $20 \%$ and to some standard antifungal recommended to oral candidiasis treatment, such as nistatin, clotrimazole, econazole and 
fluconazole. Results showed propolis and nistatin inhibited all Candida albicans strains and were significantly superior to other antifungals tested [53].

Propolis action on skin and mucosa wounds treatment has been investigated by researchers [32,33,41]. Kiderman et al. [54] case report of a one year old child affected by bilateral eosinophilic ulcers unsuccessfully treated with various products during four months. Definite cure could only be provided after lanolin-based propolis ointment application. According to authors, although circumstantial, the fact that propolis promoted wounds cure deserves further and more detailed studies concerning propolis healing properties. Pensin et al. [55] tested propolis against rats' oral mucosa ulcers, and noticed pain score diminish and wounds healing time reduction, similar to results obtained by Grégio et al. [56], Samet et al. [57] e Vieira et al. [58].

\section{Conclusion}

Propolis is a versitle drug and its great therapeutic potential has been widely studied by researchers over the world, although, it stills unknown by a considerable part of population. Therefore, this revision's findings are likely to be of great interest to health professionals and general population, concerning therapeutic indication of this peculiar drug. The number of scientific publications concerning propolis has substantially increased over the last years, and findings confirm this bee product efficiency and versatility. Propolis has antifungal, antibacterial and antiviral activities, besides anti-inflammatory and healing actions. Thus, propolis is able to assist prevention and softening of oral mucositis symptoms due to its wide biological effect, acting on all disease stages.

\section{References}

1. Sankaranarayanan R, Ramadas K, Amarasinghe H, Subramanian S, e Johnson N (2015) Oral Cancer: Prevention, Early Detection, and Treatment. In: Gelband H, Jha P,Sankaranarayanan R, Horton S, editors. Cancer: Disease Control Priorities, Third Edition (Volume 3): The International Bank for Reconstruction and Development / The World Bank Washington (DC); Chapter 5.

2. Bregman JA (2016) The Oral Cancer Epidemic. Todays FDA 28: 32-33, 35. [Crossref]

3. Macedo TB, Elias ST, Torres HM, Yamamoto-Silva FP, Silveira D, et al. (2016) Cytotoxic Effect of Erythroxylum suberosum Combined with Radiotherapy in Head and Neck Cancer Cell Lines. Braz Dent J 27: 108-12.

4. Chaveli-López B, Bagán-Sebastián JV (2016) Treatment of oral mucositis due to chemotherapy. J Clin Exp Dent 8: e201-209. [Crossref]

5. Eghbali A, Taherkhanchi B, Bagheri B, Sadeghi Sedeh B (2016) Effect of Chewing Gum on Oral Mucositis in Children Undergoing Chemotherapy: A Randomized Controlled Study. Iran J Ped Hematol Oncol 6: 9-14.

6. Al-Ansari S, Zecha JA, Barasch A, de Lange J, Rozema FR, et al. (2011) Oral Mucositis Induced By Anticancer Therapies. Curr Oral Health Rep 2: 202-211.

7. Santos RC, Dias RS, Giordani AJ, Segreto RA, Segreto HR (2011) Mucositis in head and neck cancer patients undergoing radiochemotherapy. Rev Esc Enferm USP 45: 1338-1344. [Crossref]

8. Askarifar M, Lakdizaji S, Ramzi M, Rahmani A, Jabbarzadeh F (2016) The Effects of Oral Cryotherapy on Chemotherapy-Induced Oral Mucositis in Patients Undergoing Autologous Transplantation of Blood Stem Cells: A Clinical Trial. Iran Red Crescent Med J 18: e24775.

9. Teka A, Rondevaldova J, Asfaw Z, Demissew S, Van Damme P, et al. (2015) In vitro antimicrobial activity of plants used in traditional medicine in Gurage and Silti Zones, south central Ethiopia. BMC Complement Altern Med 15: 286.

10. Chan BK, Sistrom M, Wertz JE, Kortright KE, Narayan D, et al. (2016) Phage selection restores antibiotic sensitivity in MDR Pseudomonas aeruginosa. Sci Rep 6: 26717. [Crossref]

11. Guimarães DO, Momesso LS, Pupo MT (2010) Antibióticos: importância terapêutica e perspectivas para a descoberta e desenvolvimento de novos agentes. Quim Nova 33: 667-679.
12. Parolia A, Thomas MS, Kundabala M, Mohan M (2010) Propolis and its potential uses in oral health. International Journal of Medicine and Medical Sciences 2: 210-215.

13. Pereira RF, Bártolo PJ (2016) Traditional Therapies for Skin Wound Healing. $A d v$ Wound Care (New Rochelle) 5: 208-229. [Crossref]

14. Fernandes Júnior A, Lopes MMR, Colombari V, Monteiro ACMM, Vieira EP (2006) Antimicrobial activity of Apis mellifera propolis from three regions of Brazil. Rev Rural Santa Maria 36: 294-297.

15. Lustosa SR, Galindo AB, Nunes LCC, Randau KP, Rolim Neto PJ (2008) Popolis: updates on chemistry and pharmacology. Rev Bras Farmacognosia 8: 447-454.

16. Silva-Carvalho R, Baltazar F, Almeida-Aguiar C (2015) Propolis: A Complex Natural Product with a Plethora of Biological Activities That Can Be Explored for Drug Development. Evid Based Complement Alternat Med: 206439.

17. Simões CC, Araújo DB, Araújo RPC (2008) Estudo in vitro e ex vivo da ação de diferentes concentrações de extratos de própolis frente aos microrganismos presentes na saliva de humanos. Rev. Bras. Farmacognosia 18: 84-89.

18. Bankova V (2005) Chemical diversity of propolis and the problem of standardization J Ethnopharmacol 100: 114-117. [Crossref]

19. Lawal B, Shittu OK, Abubakar AN, Olalekan IA, Jimoh AM, et al. (2016) Drug leads agents from methanol extract of Nigerian bee (Apis mellifera) propolis. $J$ Intercult Ethnopharmacol 5: 43-48. [Crossref]

20. de Mendonça IC, Porto IC, do Nascimento TG, de Souza NS, Oliveira JM, et al. (2015) Brazilian red propolis: phytochemical screening, antioxidant activity and effect against cancer cells. BMC Complement Altern Med 15: 357.

21. Sanpa S, Popova M, Bankova V, Tunkasiri T, Eitssayeam S, et al. (2015) Antibacteria Compounds from Propolis of Tetragonula laeviceps and Tetrigona melanoleuca (Hymenoptera: Apidae) from Thailand. PLoS One 10: e0126886.

22. Calhelha RC, Falcão S, Queiroz MJ, Vilas-Boas M, Ferreira IC (2014) Cytotoxicity of Portuguese propolis: the proximity of the in vitro doses for tumor and normal cell lines. Biomed Res Int 897361. [Crossref]

23. Kubiliene L, Laugaliene V, Pavilonis A, Maruska A, Majiene D, et al. (2015) Alternative preparation of propolis extracts: comparison of their composition and biological activities. BMC Complement Altern Med.15: 156.

24. Pereira EM, da Silva JL, Silva FF, De Luca MP, Ferreira EF, et al. (2011) Clinica Evidence of the Efficacy of a Mouthwash Containing Propolis for the Control of Plaque and Gingivitis: A Phase II Study. Evid Based Complement Alternat Med 2011: 750249. [Crossref]

25. Ozan F, Sümer Z, Polat ZA, Er K, Ozan U, et al. (2007) Effect of mouthrinse containing propolis on oral microorganisms and human gingival fibroblasts. Eur J Dent 1: 195201. [Crossref]

26. Dota KF, Consolaro ME, Svidzinski TI, Bruschi ML (2011) Antifungal Activity of Brazilian Propolis Microparticles against Yeasts Isolated from Vulvovaginal Candidiasis. Evid Based Complement Alternat Med 2011: 201953. [Crossref]

27. Cavalcante DR, Oliveira PS, Góis SM, Soares AF, Cardoso JC, et al. (2011) Effect of green propolis on oral epithelial dysplasia in rats. Braz J Otorhinolaryngol 77: 278284. [Crossref]

28. Armutcu F, Akyol S, Ustunsoy S, Turan FF (2015) Therapeutic potential of caffeic acid phenethyl ester and its anti-inflammatory and immunomodulatory effects (Review) Exp Ther Med 9: 1582-1588. [Crossref]

29. Franco DG (2010) Fator de transcrição nuclear kappa b no sistema nervoso central: do fisiológico ao patológico. Revista da Biologia. 4: 35-39.

30. Bufalo MC, Ferreira ICosta G, ancisco V, Liberal J, Cruz MT, et al. (2013) Propolis and its constituent caffeic acid suppress LPS-stimulated pro-inflammatory response by blocking NF-?B and MAPK activation in macrophages. J Ethnopharmacol 149: 84-92.

31. Paulino M, Alvareda E, Iribarne F, Miranda P, Espinosa V, et al. (2016) Toward the understanding of the molecular basis for the inhibition of COX-1 and COX-2 by phenolic compounds present in Uruguayan propolis and grape pomace. J Biomol Struct Dyn 8: 1-15.

32. Jacob A, Parolia A, Pau A, Davamani Amalraj F (2015) The effects of Malaysian propolis and Brazilian red propolis on connective tissue fibroblasts in the wound healing process. BMC Complement Altern Med 15: 294. [Crossref]

33. Kucharzewski M, Kózka M, Urbanek T (2013) Topical treatment of nonhealing venous leg ulcer with propolis ointment. Evid Based Complement Alternat Med 2013: 254017. [Crossref] 
34. Iyyam Pillai S, Palsamy P, Subramanian S, Kandaswamy M (2010) Wound healing properties of Indian propolis studied on excision wound-induced rats. Pharm Biol 48: 1198-1206.

35. de Moura AS, Negri G, Salatino A, Lima LD, Dourado LP, et al. (2011) Aqueous extract of brazilian green propolis: primary components, evaluation of inflammation and wound healing by using subcutaneous implanted sponges. Evid Based Complement Alternat Med: 748283.

36. Barbosa MH, Zuffi FB, Maruxo HB, Jorge LLR (2009) Therapeutic properties of propolis for treatment of skin lesions. Acta Paul Enferm 22: 318-22.

37. Volpato LE, Silva TC, Oliveira TM, Sakai VT, Machado MA (2007) Radiation therapy and chemotherapy-induced oral mucositis. Braz J Otorhinolaryngol 73: 562-568. [Crossref]

38. Simões CA, Castro JFL, Cazal C (2011) Cândida oral como fator agravante da mucosite radioinduzida. Revista Brasileira de Cancerologia 57: 23-29.

39. Chen P, Mancini M, Sonis ST, Fernandez-Martinez J, Liu J, et al. (2016) A Nove Peptide for Simultaneously Enhanced Treatment of Head and Neck Cancer and Mitigation of Oral Mucositis. PLoS One. 11: e0152995.

40. Miranda MP, Souza DS (2015) Glutamina na Prevenção e Tratamento da Mucosite em Pacientes Adultos Oncológicos: uma Revisão Sistemática da Literatura. Revista Brasileira de Cancerologia 61: 277-285.

41. Berretta AA, de Castro PA, Cavalheiro AH, Fortes VS, Bom VP, et al. (2013) Evaluation of Mucoadhesive Gels with Propolis (EPP-AF) in Preclinical Treatment of Candidiasis Vulvovaginal Infection. Evid Based Complement Alternat Med: 641480.

42. Javadzadeh Bolouri A, Pakfetrat A, Tonkaboni A, Aledavood SA, Fathi Najafi M, et al., (2015) Preventing and Therapeutic Effect of Propolis in Radiotherapy Induced Mucositis of Head and Neck Cancers: A Triple-Blind, Randomized, Placebo-Controlled Trial. Iran J Cancer Prev 8: e4019.

43. Noronha VR, Araujo GS, Gomes RT, Iwanaga SH, Barbosa MC, et al. (2014) Mucoadhesive propolis gel for prevention of radiation-induced oral mucositis. Curr Clin Pharmacol 9: 359-364. [Crossref]

44. Aghel S, Pouramir M, Moghadamnia AA, Moslemi D, Molania T, et al. (2014) Effect of Iranian Propolis on Salivary Total Antioxidant Capacity in Gamma-irradiated Rats. $J$ Dent Res Dent Clin Dent Prospects 8: 235-239. [Crossref]

45. Benderli Cihan Y, Deniz K (2011) Effect of propolis against radiation-induced ora mucositis in rats. Kulak Burun Bogaz Ihtis Derg 21: 32-41. [Crossref]

46. Gavanji S, Larki B (2015) Comparative effect of propolis of honey bee and some herbal extracts on Candida Albicans. Chin J Integr Med. [Crossref]
47. Szweda P, Gucwa K, Kurzyk E, Romanowska E, Dzierzanowska-Fangrat K, et al (2015) Essential Oils, Silver Nanoparticles and Propolis as Alternative Agents Agains Fluconazole Resistant Candida albicans, Candida glabrata and Candida krusei Clinical Isolates. Indian J Microbiol 55: 175-183.

48. Joy Sinha D, Garg P, Verma A, Malik V, Maccune ER, et al. (2015) Dentinal Tubule Disinfection with Propolis \& Two Extracts of Azadirachta indica Against Candida albicans Biofilm Formed on Tooth Substrate. Open Dent J 9: 369-374.

49. Chua EG, Parolia A, Ahlawat P, Pau A, Amalraj FD (2014) Antifungal effectiveness of various intracanal medicaments against Candida albicans: an ex-vivo study. $B M C$ Oral Health 14: 53.

50. de Castro PA, Bom VL, Brown NA, de Almeida RS, Ramalho LN, et al. (2013) Identification of the cell targets important for propolis-induced cell death in Candida albicans. Fungal Genet Biol 60: 74-86. [Crossref]

51. Freires IA, Queiroz VC, Furletti VF, Ikegaki M, de Alencar SM, et al. (2016) Chemical composition and antifungal potential of Brazilian propolis against Candida spp. $J$ Mycol Med 26: 122-132. [Crossref]

52. Siqueiraan, AB., Rodriguez, LR., Santos, RK., Marinho, RR., Abreu, S. Peixoto, RF. and Gurgel, BC., 2015. Antifungal activity of propolis against Candida species isolated from cases of chronic periodontitis. Braz Oral Res 29.

53. Martins RS, Péreira ES Jr, Lima SM, Senna MI, Mesquita RA, et al. (2002) Effect of commercial ethanol propolis extract on the in vitro growth of Candida albicans collected from HIV-seropositive and HIV-seronegative Brazilian patients with oralcandidiasis. $J$ Oral Sci 44: 41-48.

54. Kiderman A, Torten R, Furst AL, Reinus K (2001) Bi-lateral eosinophilic ulcers in an infant treated with propolis. J Dermatolog Treat 12: 29-31. [Crossref]

55. Pensin NR, Pensin C, Miura CSN, Boleta-Ceranto DC (2009) Effect of orabase própolis ointment for recurrent minor aphthous treatment - a pilot study. Arq Ciênc Saúde UNIPAR 13: 199-204.

56. Grégio AMT, de Lima AAL, Ribas MO, Barbosa APM, Pereira ACP, et al. (2005) Effect of Propolis mellifera on the repair process of ulcerated lesions in the buccal mucous of rats. Estud Biolog 27: 43-47.

57. Vieira AP, dos Santos NR, Borges JHS, Vincenzi MPA, Schmitz WO (2008) Flavonoid action in second intention healing in surgically-induced clean wounds in Wistar rats. Ciências Biológicas e da Saúde 29: 65-74.

58. Samet N, Laurent C, Susarla SM, Samet-Rubinsteen N (2007) The effect of bee propolis on recurrent aphthous stomatitis: a pilot study. Clin Oral Investig 11: 143-147. [Crossref]

Copyright: (C)2016 de Mendonça ICG. This is an open-access article distributed under the terms of the Creative Commons Attribution License, which permits unrestricted use, distribution, and reproduction in any medium, provided the original author and source are credited. 